\title{
16. FIVE TRISSOCYCLID RADIOLARIA FROM SITE 338
}

\author{
Robert M. Goll, Duke University Marine Laboratory, Beaufort, North Carolina
}

\section{INTRODUCTION}

This short contribution is intended as a supplement to the preceding chapter in which K.J. Bjorklund describes Radiolaria in Leg 38 recovery excluding the Trissocyclidae. At Bjorklund's request, I have examined four samples from Site $338(8-3,45-47 \mathrm{~cm} ; 10-2$, $60-62 \mathrm{~cm} ; 13-1,145-147 \mathrm{~cm}$; and 29-3, 123-125 cm), and I will describe the five trissocyclids (four of them new species) present in the respective assemblages. Of necessity, this analysis was hastily performed, and the sampling interval was too coarse to document the evolution of these Nassellaria with any degree of confidence. However, the material is certainly adequate to provide descriptions and biostratigraphic ranges for these taxa and to stimulate our interest in future studies based on a more refined sampling interval.

The early stages of two evolutionary lineages are preserved in Leg 38 recovery. Each lineage consists of two species and has been assigned to a separate genus. Corythospyris is a genus with three extant representatives in tropical-subtropical waters, and Corythospyris jubata $\mathrm{n}$. sp. appears to be the ancestral species to the entire Neogene diversification of this lineage. Oligocene and lower Miocene recovery from Site 338 provides us with the first preserved fossils of this important species.

Two other species recovered from Site 338 have been assigned to Clathrospyris. Both species have identical stratigraphic ranges, but $C$. camelopardalis is believed to have given rise to younger tropical progeny. It is for this reason that specimens from the Norwegian Sea are assigned to a species described by Haeckel (1887) for a skeleton from South Pacific sediments. However, the evolutionary history of this lineage is less well known than that of Corythospyris. Clathrospyris sandellae $\mathrm{n}$. sp. possesses a more "primitive" morphology and may have been indigenous to high northern latitudes. This prospect is an interesting one, because $C$. sandellae has a superficial resemblance to the single indemic high latitude trissocyclids of the Antarctic and North Pacific (Triceraspyris antarctica [Haeckel] Riedel, 1958 and Triceraspyris sp. Ling, 1975, respectively). This would indicate that the radiolarian subfauna of the northern North Atlantic had developed an indemic trissocyclid analogous to other high latitude regions. Yet, this morph disappeared at the end of the middle Miocene, when no less than four other Radiolaria became extinct. Such a significant depletion of the indemic fauna, which has not been replenished by younger species, may have been the result of a marked shift in the current regime of the North Atlantic subarctic province.

The precursors to both the Corythospyris and Clathrospyris lineages are unknown. Two species have been observed in the Oligocene of Site 338 (29-3) which may be significant. Gorgospyris quinquespina $\mathrm{n}$. sp. has a very sparce occurrence, but it has certain structural similarities with Clathrospyris sandellae (compare Plate 1, Figures 12, 15 with Plate 3, Figure 11), e.g., the shape of the sagittal ring, and the massive tuberculate lattice shell. Yet, there is a large gap in the ranges of these two taxa, and an evolutionary relationship is not apparent from Site 338 recovery. Another Eocene species observed in 29-3 is Cladoscenium ancoratum.

Three specimens of this species are illustrated in Plate 1. The construction and arrangement of basal spines on C. ancoratum are similar to those of Corythospyris. In fact, the skeletal configuration of $C$. jubata seems to be a blend of the properties of $C$. ancoratum and $G$. quinquespina.

\section{SYSTEMATIC PALEONTOLOGY}

Genus CORYTHOSPYRIS Haeckel, 1881, emend. Goll, herein Corythospyris Haeckel, 1881 , p. $443 ; 1187$, p. 1057.

Emended diagnosis: Corythospyris includes trissocyclids which have the following skeletal features: (1) a distinct pair of secondary lateral pores at the front of the basal ring (Plate 5, Figures 5, 10, 14); (2) a pair of lattice bars joining the back of the sagittal ring just above the vertical spine (Plate 4, Figure 2; Plate 5, Figure 9); and lacking sternal bar.

Type species: Elaphorspyris damaecornis Haeckel, 1887, by subsequent designation of Campbell, 1954, p. D114.

Discussion: This emendation restricts Corthospyris to a single, rather simple lineage which was formerly grouped in a complex dendrogram under the generic name Dendrospyris. Corythospyris includes the following Neogene taxa arranged from oldest to youngest as follows: $C$. jubata, n. sp.; $C$. fiscella, n. sp.; $C$. damaecornis (Haeckel) and C. stapedius (Haeckel). This anagenetic trend is characterized by a general reduction in size and loss of skeletal elements. A pair of sagittal lattice pores on the front and back of the lattice shell increases in size to such an extent that the lateral portions of the lattice shell are reduced to a single symmetrical pair of lattice bars in modern morphs.

Dictyospyris tridentata Ehrenberg, 1873, is probably assignable to Corythospyris. This species is present in tropical sediments ranging in age from middle Eocene to earliest Oligocene (Podocyrtis mitra Zone to Theocyrtis tuberosa Zone). However, it disappears in the Oligocene without leaving progeny assignable to Corythospyris, and $D$. tridentata is not regarded as ancestral to the Neogene taxa belonging to this genus.

Range: The possible diphyletic nature of this genus has been alluded to in the previous paragraph. However, if $D$. tridentata is excluded from consideration here, then the first appearance of $C$. jubata can be taken as the base of the range of Corythospyris. With this proviso, the range is Oligocene (Phorticium sp. A Zone) to Pleistocene.

Corythospyris jubata Goll n. sp.

(Plate 4, Figures 1, 2, 4, 5, 7-17)

Diagnosis: A species of Corythospyris characterized by irregularly protruding lattice spines and massive sulcate basal spines.

Name: jubatus (Latin)-having a mane.

Description: Sagittal ring subcircular, somewhat D-shaped (Plate 4, Figure 17); 48 to $57 \mu \mathrm{m}$ high; 35 to $45 \mu \mathrm{m}$ thick; joined directly to front, apex, and back of lattice shell. Vertical spine very short, obscure, arises low on the sagittal ring (Plate 4, Figures 2 and 8). Sim- 
ple apical spine slender, 18 to $30 \mu \mathrm{m}$ long, projects above lattice shell (Plate 4, Figure 7). Prominent axobate visible by bright field illumination (Plate 4, Figures 9 and 16). Frontal bar, primary and secondary lateral bars joined to basal ring.

Basal ring oval, not constricted sagittally; 46 to $63 \mu \mathrm{m}$ wide; 38 to $44 \mu \mathrm{m}$ thick; joined to frontal bar and directly to back of sagittal ring; and encloses three pairs of basal pores. Smallest pair of basal pores (secondary lateral pores) at front of basal ring, framed by frontal bar and secondary lateral bars, most clearly visible in front view (Plate 4, Figure 11). Lattice shell 53 to $70 \mu \mathrm{m}$ high, 76 to $95 \mu \mathrm{m}$ wide, slightly constricted by sagittal ring, and does not extend below sagittal ring. Development of lattice shell somewhat variable. Some specimens have a plate of lattice protruding from the front of the lattice shell and joined to the distal end of the basal spine (Plate 4, Figure 1). This extension is absent on other individuals (Plate 4, Figure 10). Three basal lattice spines are massive, circular in cross-section, 35 to $44 \mu \mathrm{m}$ long, of approximately equal length, irregularly sulcate distally, project obliquely from the basal ring at the positions of the frontal and primary lateral bars (Plate 4, Figures 7, 10, and 13). Short spines project from lateral surfaces of lattice shell in a chaotic manner. Lattice bars are massive, slightly tuberculate, frame subcircular lattice pores 3 to $25 \mu \mathrm{m}$ in diameter. Lattice pores are densely spaced but irregularly arranged, except for the six pairs of sagittal lattice pores, which are larger and occupy fixed positions. Lattice bars joined to basal ring display little uniformity, but lattice bars never occur adjacent to the secondary lateral bars.

Holotype: Plate 4, Figures 14-18; locality: 338-13-1, 145-147 cm; repository: U.S. National Museum, Washington, D.C.

Remarks: Corythospyris jubata appears to be the precursor to Corythospyris fiscella and younger members of this lineage. The massive spinous development of the lattice shell easily distinguishes C. jubata from all other Corythospyris taxa, including the type species, C. damaecornis Haeckel, 1887. The ancestry of C. jubata is uncertain.

Occurrence: Corythospyris jubata has not been observed in siliceous sediments of equivalent age from other localities. This species is referred to as Trissocyclidae sp. A on the stratigraphic range chart of Bjorklund (this volume, Table 24). However, the definition of $C$. jubata differs slightly from the concept used by Bjorklund, and C. jubata has been observed in somewhat younger sediments. At Site $338, C$. jubata has a common and continuous occurrence from Sections 10-2 to 19-3 as well as scarce, sporatic occurrences in Sections $21-1,22-4$, and 23-3. These oldest scarce occurrences may be the result of reworking. Conversely, these occurrences may indicate that the Norwegian Sea was periphęral to the province of $C$. jubata during its early history (Phorticium sp. A Zone to Ceratocyrtis robustus Zone). During the late Oligocene (Velicucullus oddgurneri Zone), both C. jubata and its descentant species $C$. fiscella migrated into the Norwegian Sea, where they subsequently maintained continuous populations until middle Miocene time. Corythospyris jubata disappears in Section 10-2.

\section{Corythospyris fiscella Goll n. sp.}

$$
\text { (Plate 5, Figures 1-21) }
$$

Diagnosis: A species of Corythospyris characterized by a small, smooth, uniformly perforated lattice shell and fice pairs of lattice bars joined to the sagittal ring.

Name: fiscella (Latin)—a small wickerwork basket.

Description: Sagittal ring small, subcircular, somewhat D-shaped (Plate 5 , Figures 13 and 17 ); 38 to $54 \mu \mathrm{m}$ high; 30 to $38 \mu \mathrm{m}$ thick; joined directly to front apex, and back to sagittal ring. Vertical spine short, obscure, arises low on the sagittal ring (Plate 5, Figures 9 and 11). Simple apical spine slender, 4 to $10 \mu \mathrm{m}$ long, barely visible or incomplete on many specimens. Small axobate faintly visible by bright-field illumination. Frontal bar, primary and secondary lateral bars joined to basal ring.

Basal ring oval, slightly constricted sagittally and latterally, 39 to $52 \mu \mathrm{m}$ wide, 33 to $40 \mu \mathrm{m}$ thick, joined to frontal bar and directly to back of sagittal ring, and encloses three pairs of basal pores. Prominence of secondary lateral pores in front view more distinct than on specimens of Corythospyris jubata n. sp. (Plate 5, Figures 5 and 19). Lattice shell 40 to $53 \mu \mathrm{m}$ high, 60 to $77 \mu \mathrm{m}$ wide, and slightly constricted by sagittal ring. Lattice shell does not extend below basal ring on most specimens. A few specimens have small plate of lattice below the back of basal ring which frames a single sternal pore (Plate 5, Figure 9. Three slender basal lattice spines project obliquely from basal ring at the positions of the frontal and primary lateral bars. These basal lattice spines are 12 to $20 \mu \mathrm{m}$ long, taper to a simple point on most specimens. A few individuals have longer basal lattice spines with a symmettrical pair of short by-spines near the distal end which imparts a "trident" appearance. Lattice shell smooth, thin-walled, densely perforated by subcircular lattice pores 3 to $28 \mu \mathrm{m}$ in diameter. These lattice pores are irregularly distirbuted except for the sagittal lattice pores, which are large and occupy fixed positions. Four or five lattice bars are joined to each side of the basal ring; none are present at the position of the primary lateral bars. Spines are not present on the lateral surfaces of the lattice shell, except for rare individuals (i.e., Plate 5, Figures 1-4) which bear short lattice spines surrounding incompletely latticed areas.

Holotype: Plate 5, Figures 14-18; locality: 338-13-1, 145-147 cm; repository: U.S. National Museum, Washington, D.C.

Discussion: Corythospyris fiscella is distinguished from all younger members of this lineage by the constancy of the sagittal lattice pore and bar arrangement. Goll (1968) transferred Corytospyris damaecornis (Haeckel) to Dendrospyris and broadened its definition to include specimens here described as Corythospyris fiscella. However, this revision now appears to have been unwise, and the name Corythospyris damaecornis should be restricted to nonspinous individuals bearing two pairs of enlarged sagittal lattice pores, such that the lattice shell is restricted to a narrow lateral band. This usage is more compatible with its original deginition.

Reference has been made to Dictyospyris tridentata Ehrenberg in the discussion section of the genus Corythospyris. This species is a remarkable homeomorph of Corythospyris fiscella in Barbados sediments of the Bath Cliff Formation. However, it differs from $C$. fiscella in the variable number of sagittal lattice bars and its prominent tribladed apical spine.

Occurrence: Corythospyris fiscella ranges from Sections 8-3 to 18-6 at Site 338. This species is referred to as Trissocyclidae sp. B in the stratigraphic range chart of Bjorklund (this volume, Table 24). However, the range of $C$. fiscella extendsslightly higher than is indicated by Bjorklund, and the total occurrence is upper Velicucullus oddgurneri Zone toLithomelissa stigi Zone (late Oligocene to middle Miocene).

\section{Clathrospyris Haeckel, emend. Goll}

Clathrospyris Haeckel, 1887, p. 442; 1887, p. 1052; Campbell, 1954, p. D113.

Emended diagnosis: Clathrospyris includes trissocyclids having: (1) an axobate, (2) five pairs of lattice bars joined to the sagittal ring at uniform positions, (3) no secondary lateral bars or pores and no tertiary-lateral bars, and (4) no sternal bar and sternal pore.

Type species: Clathrospyris camelopardalis Haeckel (1887) by subsequent designation of Campbell (1954), p. D113.

Discussion: Haeckel defined this genus to include those pentaspyrids (five basal spines) with a single apical spine. Although the occurrence of five basal spines is common to many specimens, it is not a conservative property. At the present time, I conclude that the number of spines has little evolutionary significance for these particular organisms and is not useful as a diagnostic character at the generic level. Conversely, the occurrence of five pairs of lattice bars joined to the sagittal ring appears to be constant property which has been observed on several undescribed mid-Tertiary trissocyclids taxa in equatorial sediments as well as the two new species described here. Uniformity applies not only to the number of lattice bar pairs, but also to the positions where they are joined to the sagittal ring. One pair of lattice bars joins the sagittal ring at the base of the apical spine. A second pair is located at the approximate midpoint of the front of the ring. The three remaining pairs of lattice bars are joined to the top and back of the sagittal ring between the apical and vertical spines. The modern species, Dictyocircus clathratus Jørgensen, 1905, is also probably assignable to Clathrospyris in its emended sense. Due to the occurrence of a sternal bar and sternal pore, Giraffospyris annulispina Goll, 1969, is excluded from this genus. This latter species is not regarded as a close relative of the Clathrospyris lineage, although many specimens of $G$. annulispina bear the lattice bar arrangement which is diagnostic for the genus.

Range: In Leg 38, Clathrospyris ranges from $338-8-2,120-122 \mathrm{~cm}$ to $12-2,145-147 \mathrm{~cm}$, upper lower Miocene to upper middle Miocene. The two clathrospyris species described here are collectively referred to as Triceraspyris sp. by Bjørklund (this volume, Table 24). His chart gives the range of this genus as Stichocorys biconica Zone to Lithomelissa stigi Zone. Presumably, Site 338 includes the evolutionary first appearance of Clathrospyris, but the genus is believed to include extant taxa and the complete range of Clathrospyris is lower Miocene to Pleistocene. 
Clathrospyris camelopardalis Heckel, emend. Goll

(Plate 1, Figures 4, 5, 9, 10, 13, 14; Plate 2, Figure 1)

Clathrospyris camelopardalis Heckel, 1887, p. 1052.

Emended diagnosis: Aspecies of Clathrospyris characterized by a massive tuberculate lattice shell which does not extend below the basal ring and five or more simple basal spines of approximately equal length.

Description: Sagittal ring large, subpolygonal; 59 to $74 \mu \mathrm{m}$ high; 42 to $55 \mu \mathrm{m}$ thick; joined directly to front, apex, and back of lattice shell. Front of sagittal ring bears a broad longitudinal ridge (Plate 1, Figure 1a4). Broad vertical spine arises at approximate midpoint of sagittal ring, located in middle of lowest pair of sagittal lattice pores (Plate 1, Figure 9; Plate 2, Figure 1). Simple apical spine short, stout, inconspicuous on most specimens. Primary lateral bars joined to basal ring.

Basal ring subcircular, constricted sagittally; 70 to $85 \mu \mathrm{m}$ wide; 62 to 77 $\mu \mathrm{m}$ thick; joined directly to front and back of sagittal ring; encloses two pairs of basal pores, of which the back pair is equal in size or larger than the fron pair. Lattice shell 68 to $79 \mu \mathrm{m}$ high, 84 to $105 \mu \mathrm{m}$ wide, slightly constricted by sagittal ring, and does not extend below basal ring. Basal spines, 10 to 44 $\mu \mathrm{m}$ long, project downward from basal ring; are subcircular in cross-section; of approximately equal length; and taper to a simple point. Three such basal spines are located at the positions of the primary lateral bars and the front of the sagittal ring. One or two additional pairs of basal spines project from the lateral surfaces of the basal ring to make a variable total of five to seven spines, respectively. Lattice bars are massive, variably tuberculate (Plate 1, Figue 4; Plate, Figure 1), frame subcircular lattice pores ranging in diameter from 10 to $35 \mu \mathrm{m}$. Lattice pores are densely spaced, and irregularly arranged on lateral surfaces. Six pairs of sagittal lattice pores are large and maintain fixed positions.

Holotype: Plate 1, Figures 13, 14; locality: 338-10-2, 60-62 cm; repository: U. S. National Museum, Washington, D. C.

Remarks: Clathrospyris camelopardalis resembles Tholospyris anthopora (Haeckel) Goll, 1968, but can be distinguished from the latter species by its smaller overall size, smaller pores, less massive lattice bars, and the presence of basal lattice spines. Tholospyris anthorpora has four pairs of lattice bars joined to the sagittal ring.

Occurrence: The stratigraphic ranges of $C$. camelopardalis and $C$. sandellae are identical, and the information given under Clathrospyris for Site 338 applies to $c$. camelopardalis. This species is believed to have given rise to younger morphs in tropical sediments, but these taxa are undescribed, and no range data can be provided here.

\section{Clathrospyris sandellae Goll, n. sp.} (Plate 5, Figures 1-21)

Diagnosis: A species of Clathrospyris characterized by the presence of a massive tuberculate lattice shell which extends below the sagittal ring.

Name: sandellae - in honor of Sandella Walker, who assisted me in my research at Lamont-Doherty Geological Laboratory.

Description: Sagittal ring tall, subpolygonal (Plate 2, Figure 3; Plate3, Figure 5); 66 to $80 \mu \mathrm{m}$ high; 50 to $65 \mu \mathrm{m}$ thick; joined directly to front, top, and back of lattice shell. Front of sagittal ring bears a longitudinal external ridge (Plate 2, Figures 8 and 11). Broad vertical spine arises at approximate midpoint of sagittal ring, located in middle of lowest pair of sagittal lattice pores (Plate 3, Figures 4 and 11). Simple apical spine short, slender, inconspicuous on most specimens. Small axobate faintly visible under bright-field illunination (Plate 2, Figures 6 and 9). Primary lateral bars joined to basal ring.

Basal ring inflated, subcircular, strongly constricted sagitally; 87 to 104 $\mu \mathrm{m}$ wide; 60 to $95 \mu \mathrm{m}$ thick; joined directly to front and back of sagittal ring; and encloses two pairs of basal pores, of which the back is pair is equal in size or larger than the front pair (Plate 2, Figure 6 and 9; Plate 3, Figure 8). Lattice shell 75 to $104 \mu \mathrm{m}$ high, 95 to $140 \mu \mathrm{m}$ wide, and extneds below basal ring as short "skirt" of lattice joining the basal spines in an irregular trellis (Plate 2, Figue 11; Plate 3, Figures 1 and 11). This basal lattice extension is very delicate and incompletely preserved on many specimens, but serrated margins on the basal ring and basal spines indicate its original presence (Plate 3, Figure 2). A delicate plate of lattice surrounds the lower front of the sagittal ring of some specimens (Plate 2, Figure 5; Plate 3, Figures 2 and 9) in a manner similar to that described for Corythospyris jubata n. sp. Constriction of lattice shell by sagittal ring varies from slight on some specimens (Plate 3, Figure 10) to quite pronounced on others (Plate 2, Figue 4). Rare specimens have a loosely trellised plate of lattice extending over the top of the sagittal ring and joined to the apical spine (Plate 2, Figure 8). Basal spines five to nine in number, originate at basal ring, project obliquely downward, extend 25 to $40 \mu \mathrm{m}$ below lattice "skirt," are subcircular in cross-section, of approximately equal length, and taper to a simple point. Lattice bars massive, tuberculate, frame subcircular pores 5 to $22 \mu \mathrm{m}$ in diameter on most specimens (Plate 3, Figure 11). Rare individuals have thin smooth lattice bars (Plate 2, Figure 10). Pores on lateral portions of lattice shell display no discernible organization. Six symmetrical pairs of large lattice pores occupy regular positions around the sagittal ring.

Holotype: Plate 3, Figures 6-11; locality: 338-10-2, 60-62 cm; repository: U. S. National Museum, Washington, D. C.

Remarks: Clathrospyris sandellae bears a strong resemblance to Triceraspyris antarctica (Haecker) Riedel, 1959. A manuscript is now in progress which deals with the taxonomic status of the latter species. The major difference between these two high latitude morphs is the arrangement by which the lattice shell joins to the sagittal ring. Unlike $C$. sandellae, Triceraspyris antarctica displays poor organization in the positions and number of lattice bar pairs joined to the sagittal ring; the number varies from 9 to 20 . Consequently, the sizes of the intervening sagittal lattice pores are quite small and approximately equidimensional to other lattice pores. Clathrospyris sandellae has only five pairs of lattice bars joined to the sagittal ring, and intervening sagittal lattice pores are quite large in comparison to those ot $T$. antarctica.

Occurrence: Clathrospyris sandellae is regarded as an indigenous Arctic or Subarctic trissocyclid. Range data for this species are identical to the range for Clathrospyris at Site 338.

\section{Gorgospyris quinquespine Goll n. sp.}

(Plate 1, Figures 11, 12, 15)

Diagnosis: A species of Gorgospyris characterized by five basal pores, five basal spines, and a short apical spine.

Name: quinque (Latin—five, spina (Latin)—spine.

Description: Sagittal ring large, subpolygonal; 55 to $67 \mu \mathrm{m}$ tall; 47 to 53 $\mu \mathrm{m}$ thick; joined directly to top and back of lattice shell. Vertical spine short, broad, recessed within lattice shell, arises at the approximate midpoint of sagittal ring. Simple apical spine short, stout, does not protrude above lattice shell. One or two pairs of connector bars are joined to lower front of sagittal ring. An axobate is not visible. Frontal bar, primary and secondary lateral bars joined to basal ring.

Basal ring subtriangular, strongly constricted sagittally and laterally; 62 to $70 \mu \mathrm{m}$ wide, 41 to $48 \mu \mathrm{m}$ thick; joined to frontal bar and free from back of sagittal ring; encloses five basal pores. Very small pair of basal pores in front of basal ring are secondary lateral pores, framed by frontal bar and secondary lateral bars. Large pair of basal pores are framed by primary and secondary lateral pores. Single odd basal pore framed by primary lateral bars and back of basal ring (Plate 1, Figure 11). Lattice shell inflated, 70 to $86 \mu \mathrm{m}$ high, 93 to $105 \mu \mathrm{m}$ wide, slightly constricted by sagittal ring, does not extend below basal ring. Five basal spines project obliquely from basal ring, are 23 to 36 $\mu \mathrm{m}$ long, subcircular in cross-section, of approximately equal length, and taper to a simple point. One basal spine projects as an extension of the frontal bar; two basal spines are located at the lateral extremes of the basal ring; a pair of lattice pores separates the second set of basal spines from the basal ring at the position of the primary lateral bars. Lattice bars massive, totally tuberculate, frame subcircular pores 4 to $10 \mu \mathrm{m}$ in diameter. Five to seven pairs of lattice bars are joined to top and back sagittal ring between the apical and vertical spines. Lattice pores densely spaced, of approximately equal size, Sagittal lattice pores equal in size to other lattice pores.

Holotype: Plate 1, Figures 11, 12, 15; locality: 338-29-3, 123-125 cm; repository: U. S. National Museum, Washington, D. C.

Remarks: The definition of this species is based on only six specimens observed in Sample 29-3, 123-125 cm. However, the number and arrangement of basal spines are uniform within this small sample, and $G$. quinquespina has been observed in upper Eocene-lower Oligocene tropical sediments as well.

\section{REFERENCES}

Campbell, A. S., 1954. Radiolaria. In Moore, R. C. (Ed.), Treatise on invertebrate paleontology: Kansas (Univ. 
Kansas Press and Geol. Soc. Am.) Pt. D., Protista 3, p. 11.

Goll, R.M., 1968. Classification and phylogeny of Cenozoic Trissocyclidae (Radiolaria) in the Pacific and Caribbean basins: J. Paleontol., v. 42, p. 1409.

Haeckel, E., 1881. Entwurf eines Radiolarien-Systems auf Grun von Studien der Challenger-Radiolarien: Jena Z. Med. Naturwiss., v. 15, p. 418.
1887. Report on the Radiolaria collected by H.M.S. Challenger during the years 1873-76: Rept. Voyage Challenger, Zool., v. 18.

Ling, H.Y., 1975. Radiolaria: Leg 31 of the Deep Sea Drilling Project. In Karig, D.E., Ingle, J.C., et al., Initial Reports of the Deep Sea Drilling Project, Volume 31: Washington (U.S. Government Printing Office), p. 703.

Riedel, W.R., 1958. Radiolaria in Antarctic sediments: Rept. B.A.N.Z. Antarct. Res. Exped., ser. B, v. 6, p. 217. 



\section{PLATE 1}

All specimens $\times 400$.

Figures 1-3, 6-8 Cladoscenium ancoratum Haeckel. All from Sample $338-29-3,123-125 \mathrm{~cm}$.

1-3. Oblique back view focused on upper, middle and lower surfaces of lattice shell, respectively.

6. Back view of specimen showing bladed basal spines with three bispines near distal end.

7,8 . Side view of specimen showing apical spine similar to basal spines, focused on interior and outer surface of lattice shell, respectively.

Figures 4, 5, 9, Clathrospyris camelopardalis Haeckel. All from $10,13,14$ Sample 338-10-2, 60-62 cm.

4. Front view.

$5,9,10$. Front, oblique back and back views, respectively.

13, 14. Front views focused on outer surface of lattice shell and sagittal ring, respectively.

Figures 11, 12, Gorgospyris quinqueramus Goll n. sp. Sample 338-

$29-3,123-125 \mathrm{~cm}$. Specimen containing debris within the lattice shell. Basal view, front view focused on lattice shell, front view focused on basal spine, respectively. 
PLATE 1
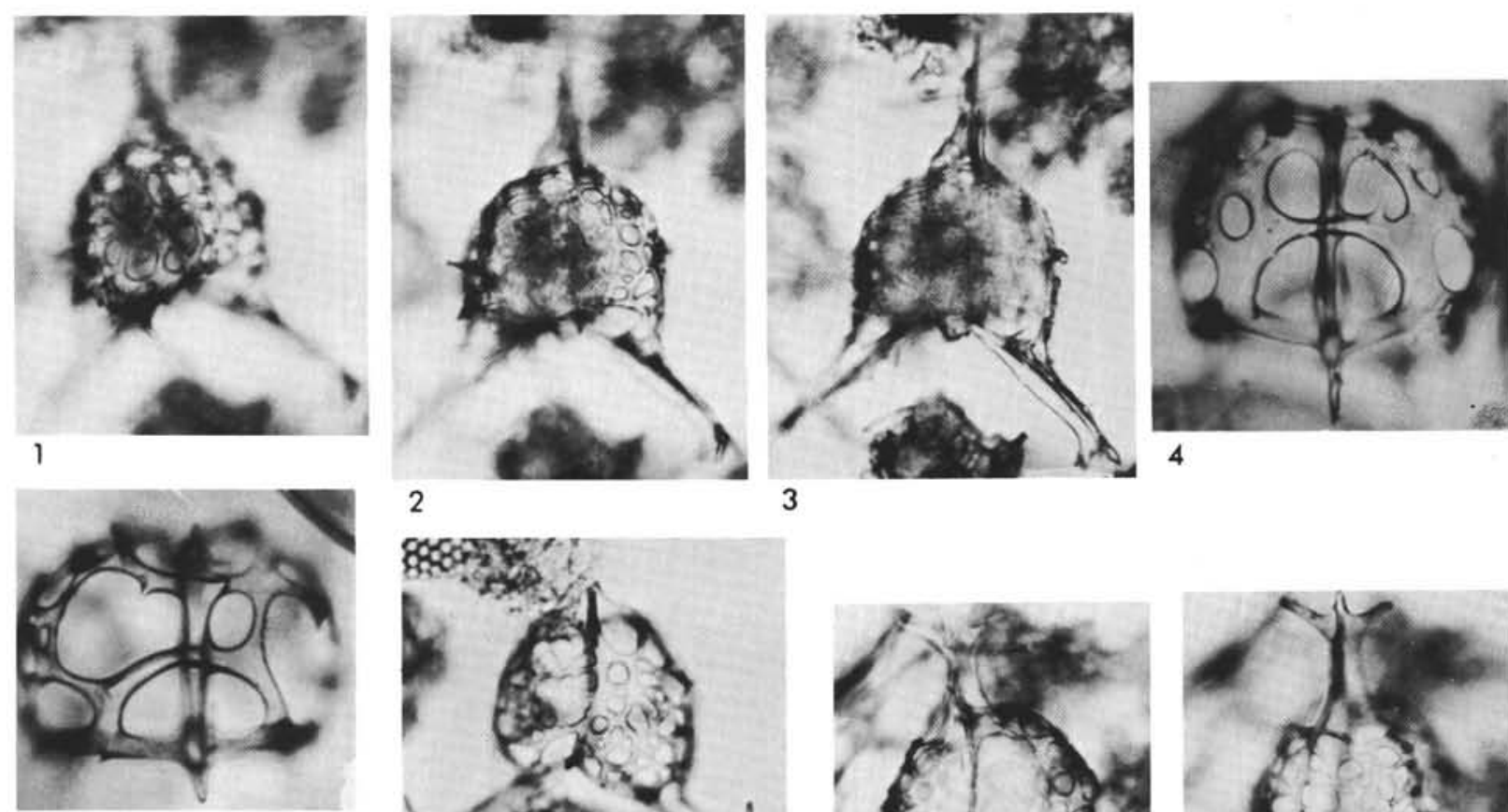

5
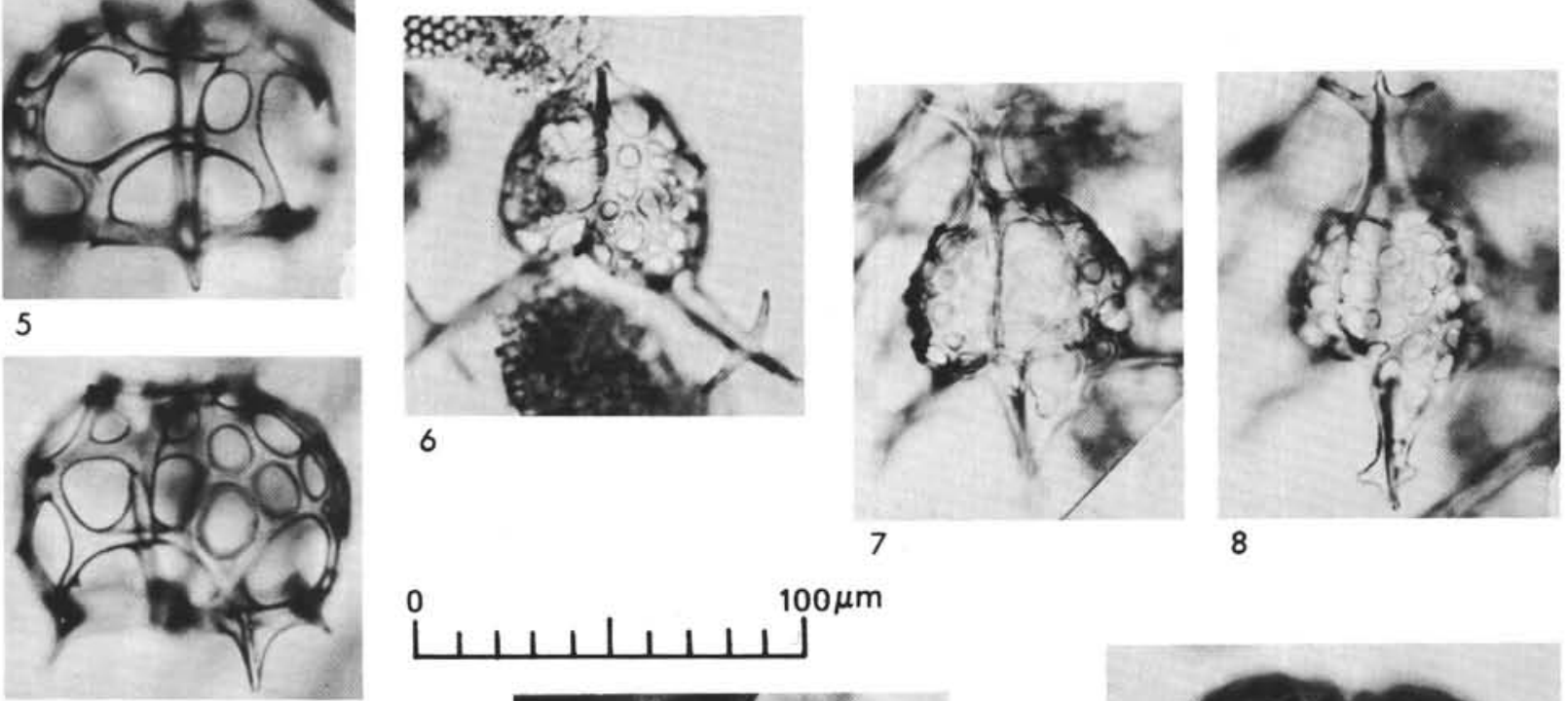

\section{$0 \quad 100 \mu \mathrm{m}$}
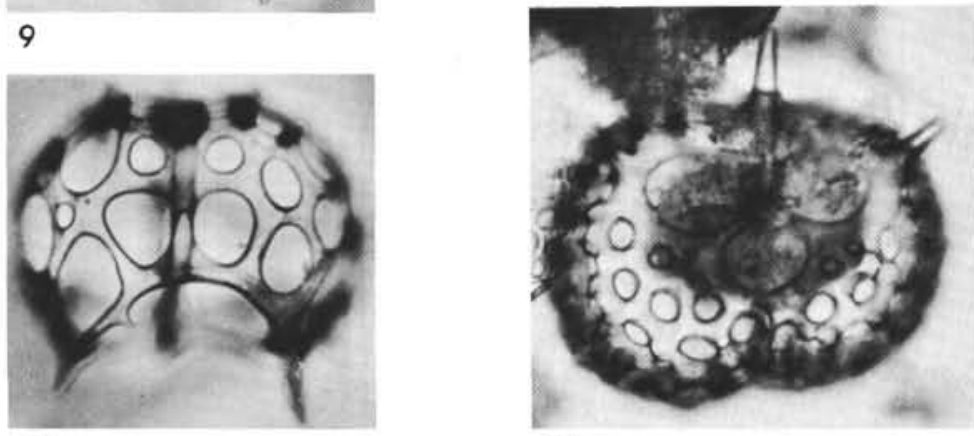

10

11

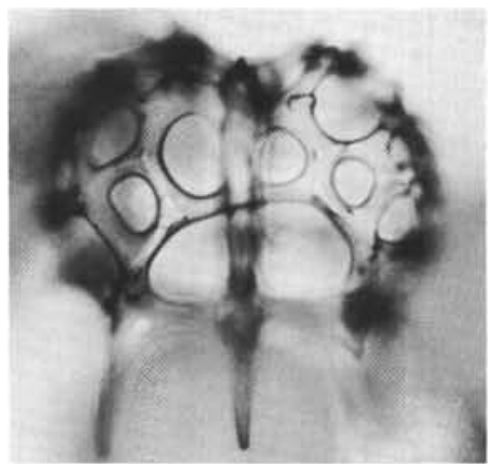

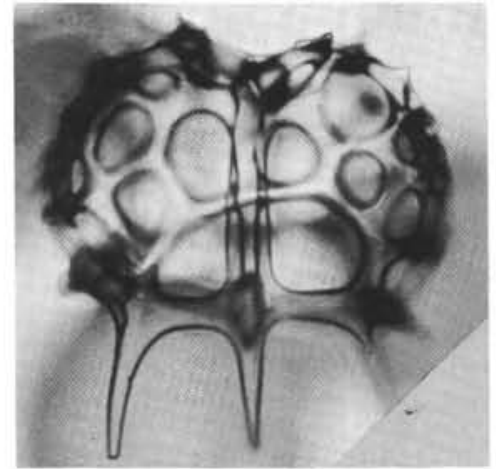

14

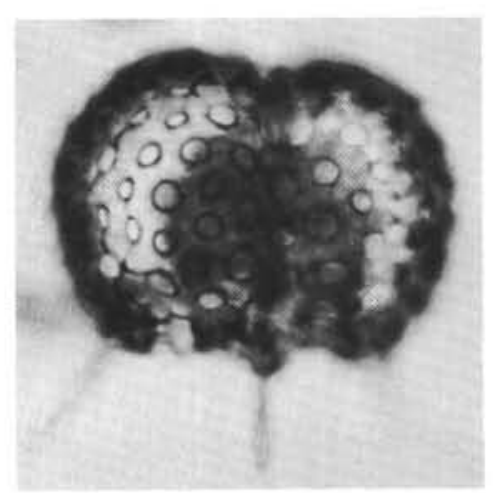

12

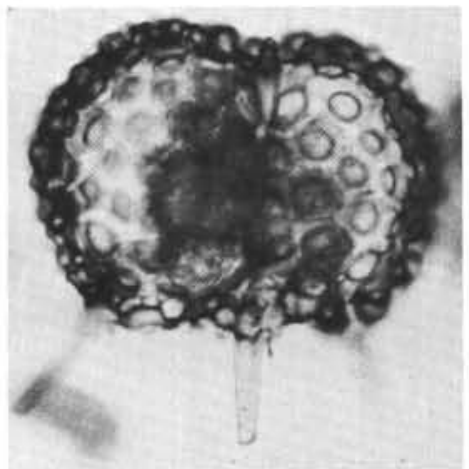

15 


\section{PLATE 2}

All specimens $\times 400$.

Figure 1

Clathrospyris camelopardalis Haeckel. Sample $338-10-2,60-62 \mathrm{~cm}$, back view.

Figures 2-11 Clathrospyris sandellae Goll, n. sp. All from Sample $338-10-2,60-62 \mathrm{~cm}$.

2, 3. Right-side views focused on outer lattice shell and sagittal ring, respectively.

4-6. Front views, focused on lattice extension and lattice shell, and basal view, respectively.

7 , 8. Front views, focused on outer lattice shell and sagittal ring, respectively.

9-11. Basal view and front views, focused on outer surface of lattice shell and sagittal ring, respectively 
PLATE 2
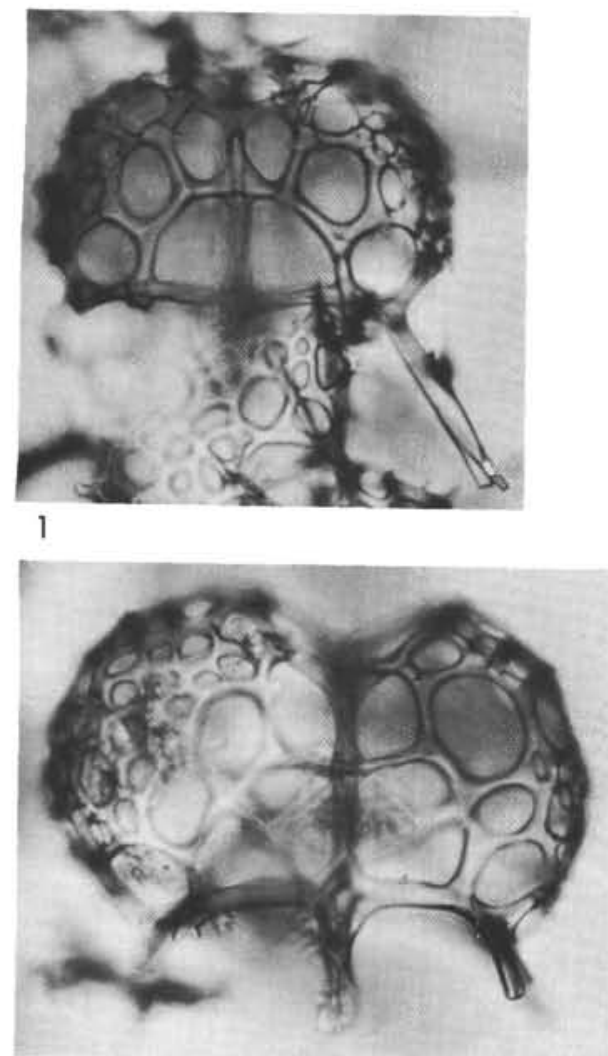

$$
4
$$
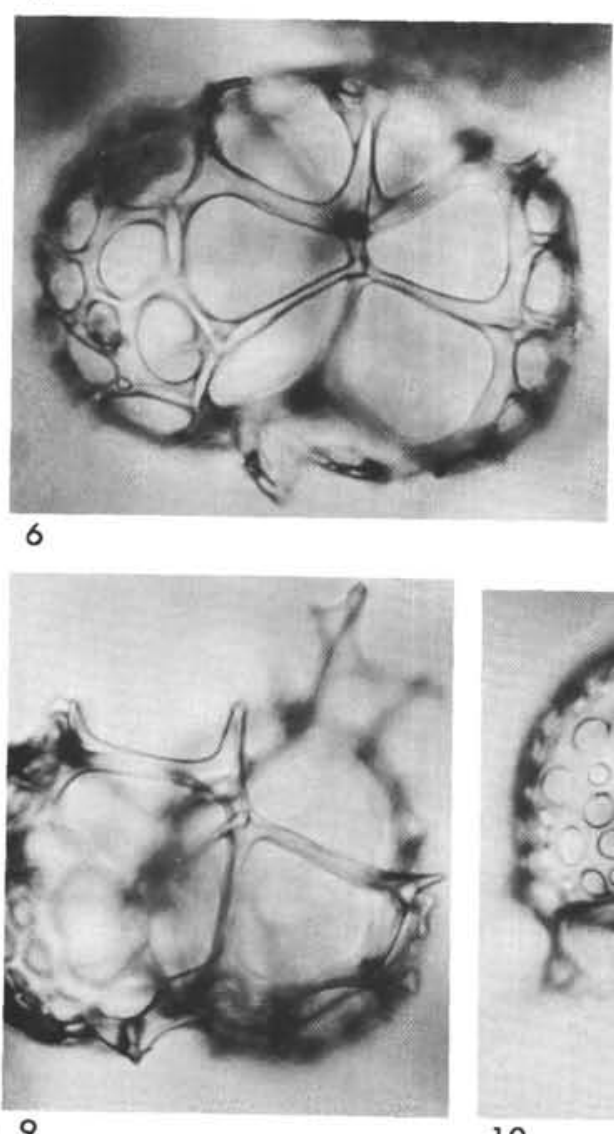
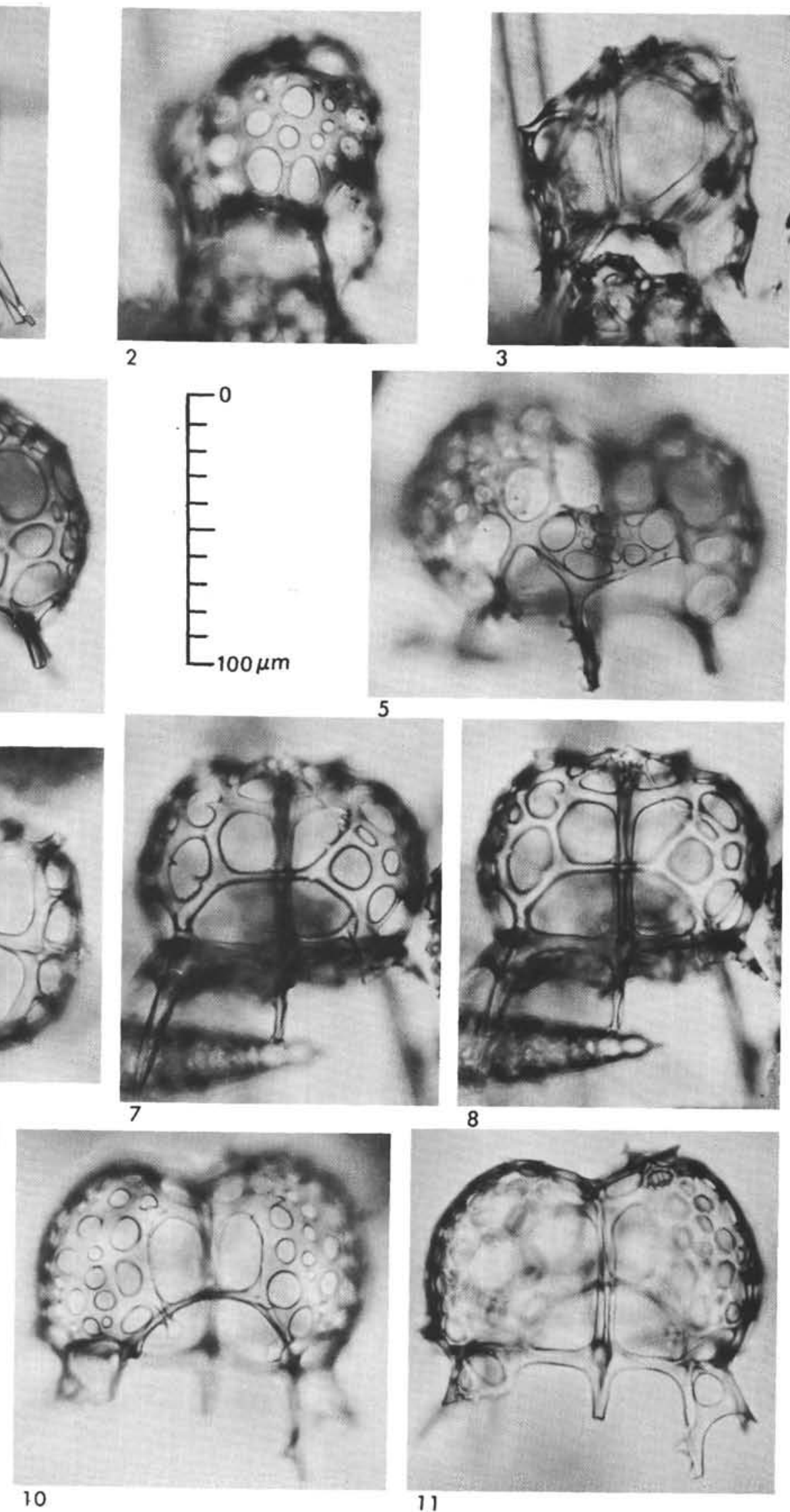


\section{PLATE 3}

All specimens $\times 400$.

Figures 1-11 Clathrospyris sandellae Goll, n. sp. All from Sample $338-10-2,60-62 \mathrm{~cm}$.

1, 4. Oblique back and back views, respectively.

2,3 . Oblique front views focused on outer surface of lattice shell and sagittal ring, respectively.

5. Right-side view of incomplete specimen showing sagittal ring.

6-11. Left-side views focused on lattice shell and sagittal ring, basal view, front views focused on lattice shell and sagittal ring and back view, respectively. 
PLATE 3
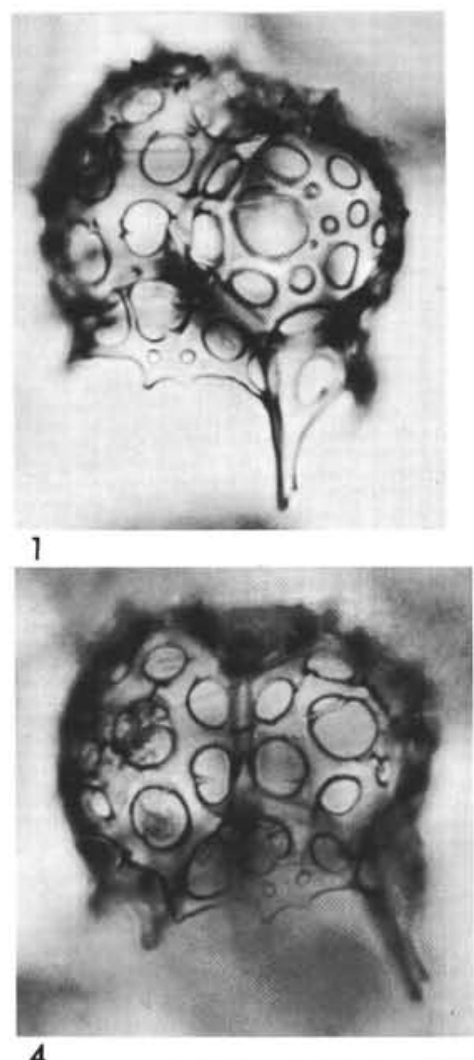

4

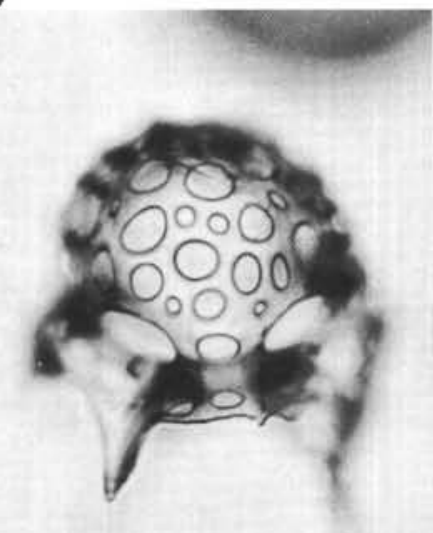

6

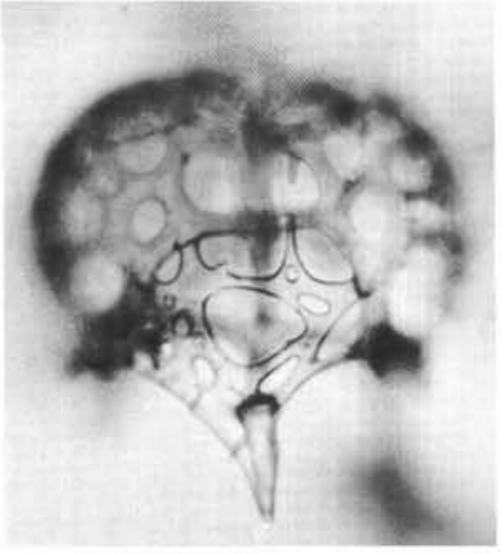

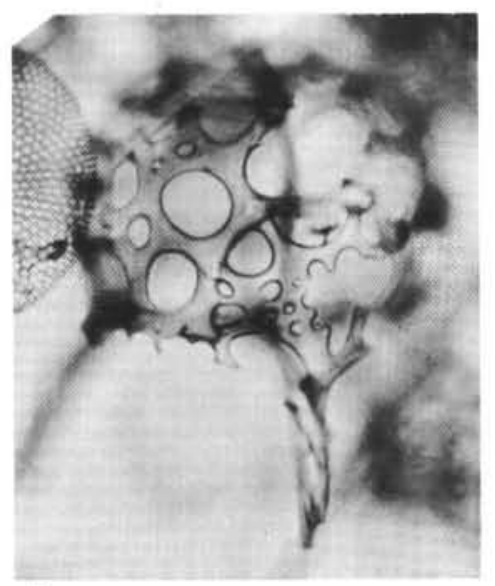

2
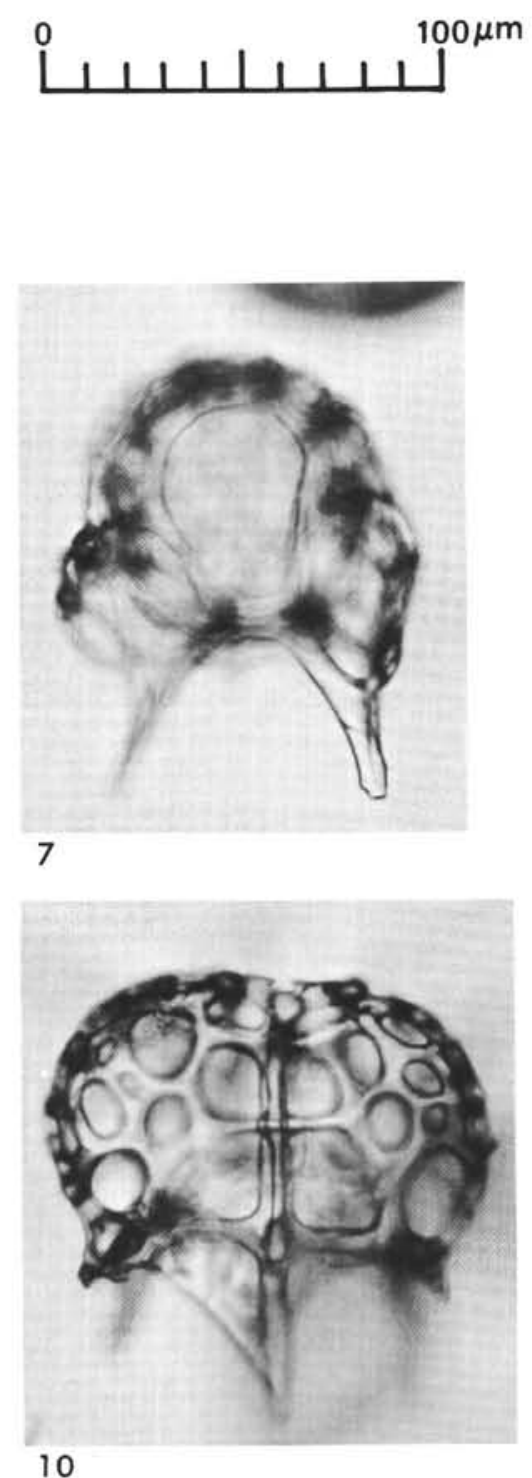

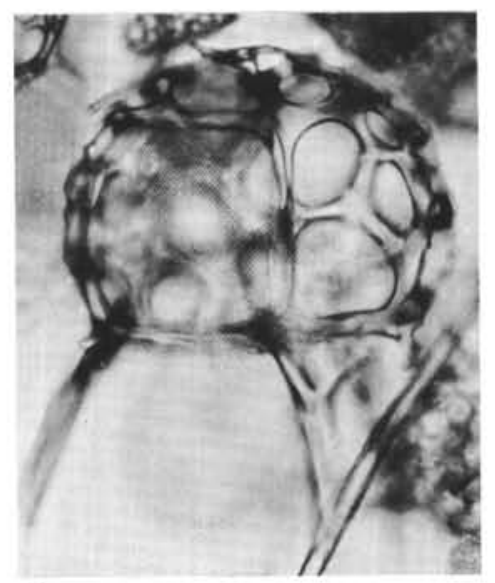

3
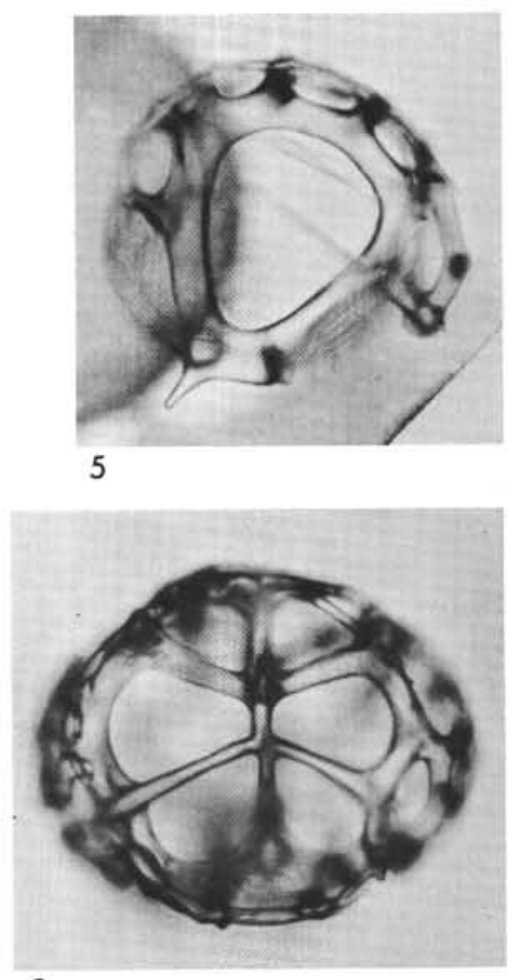

8

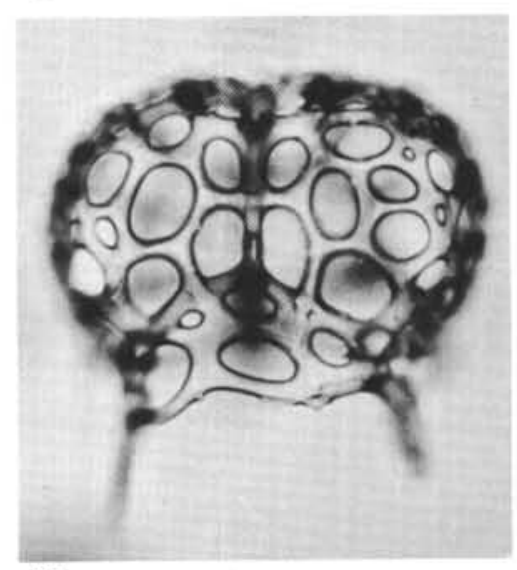

11 


\section{PLATE 4}

All specimens $\times 400$.

Figures 3,6 Specimen transitional between Corythospyris jubata and Corythospyris fiscella. Sample 338-8-3, $45-47 \mathrm{~cm}$, front views focused on basal lattice spine and lattice shell, respectively.

Figures 1, 2, 4, 5,Corythospyris jubata Goll, n. sp.

7-17 1, 4, 7. Sample 338-13-1, 145-147 cm, front views focused on upper, middle, and lower surfaces of lattice shell, respectively.

2 , 5. Sample 338-13-1, 145-147 cm, oblique back views focused on upper and middle surfaces of lattice shell, respectively.

8 , 9. Sample $338-10-2,60-62 \mathrm{~cm}$, back view and basal view, respectively.

10-17. Sample 338-13-1, 145-147 cm.

$10-12$. Front views focused on upper middle and lower surfaces of lattice shell, respectively.

13, 17. Right-side views focused on lattice shell and sagittal ring, respectively.

14,15 . Basal views focused on basal ring and basal lattice spines, respecitvely.

16. Oblique basal view. 
PLATE 4
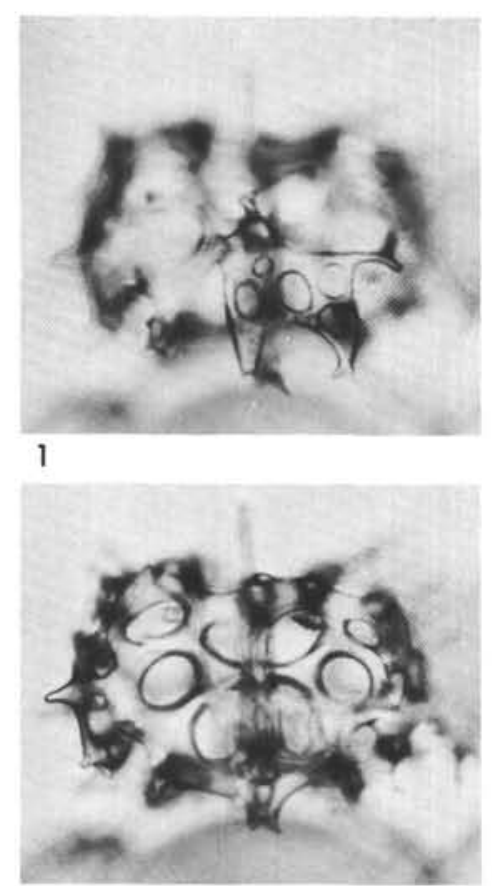

4

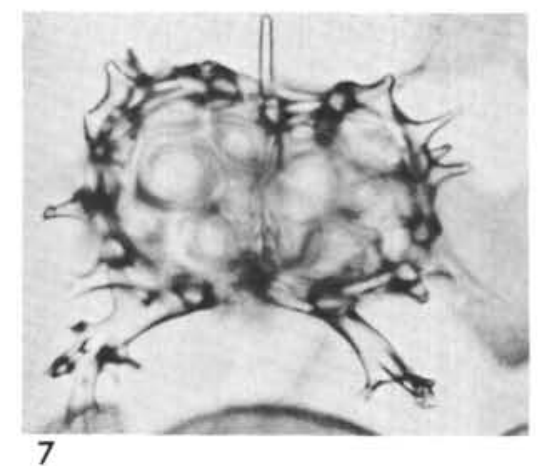

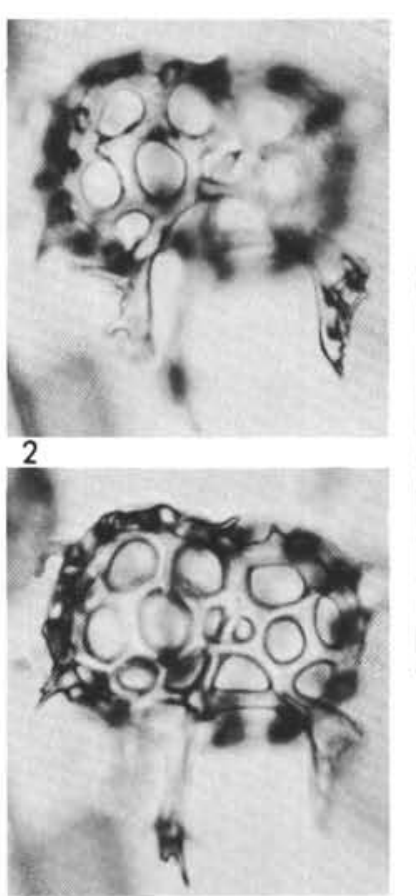

5

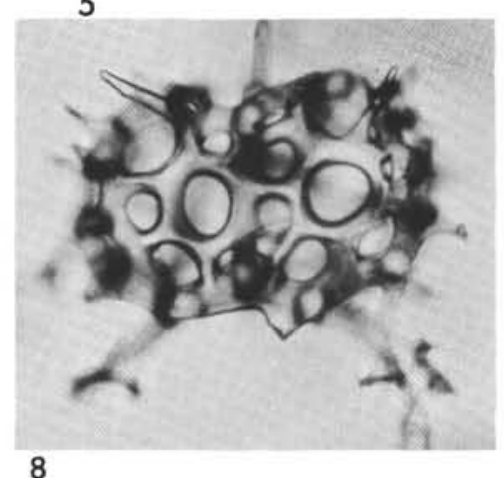

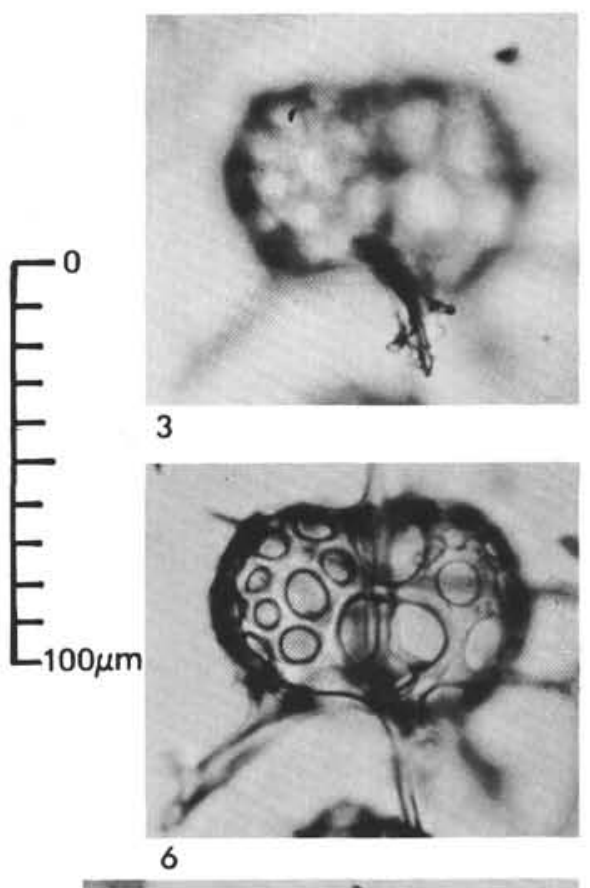
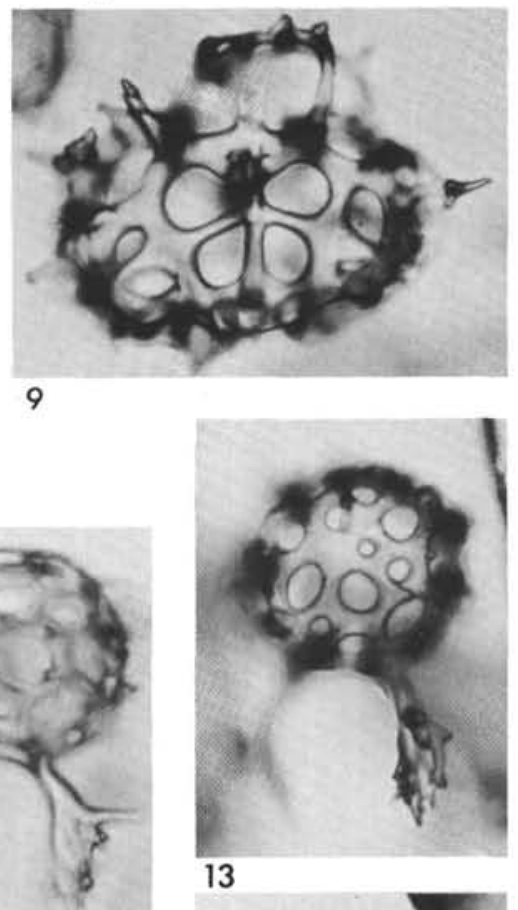

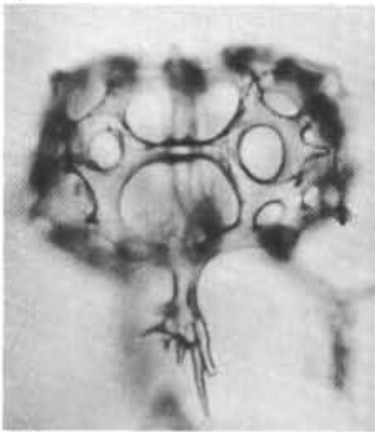

10

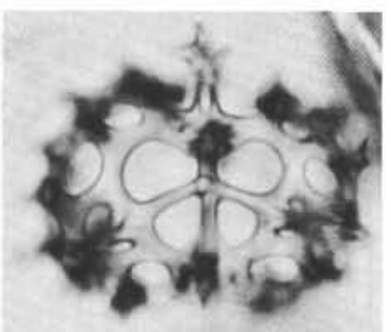

14

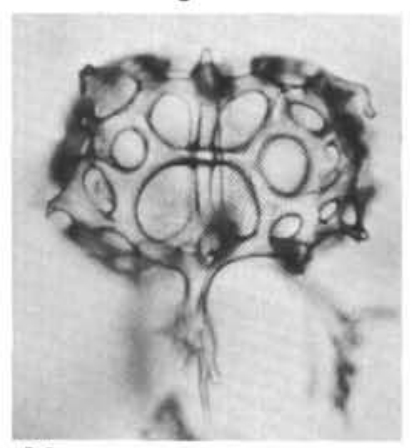

11

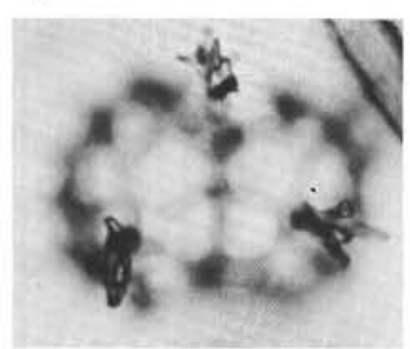

15

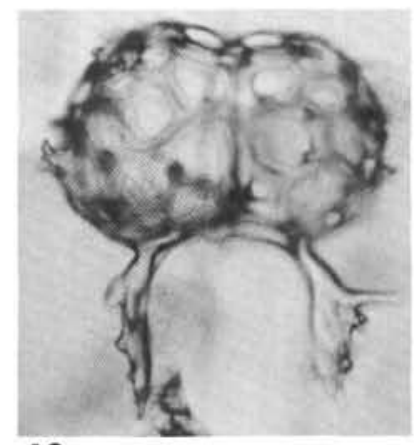

12

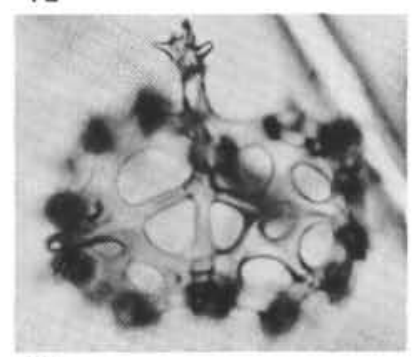

16

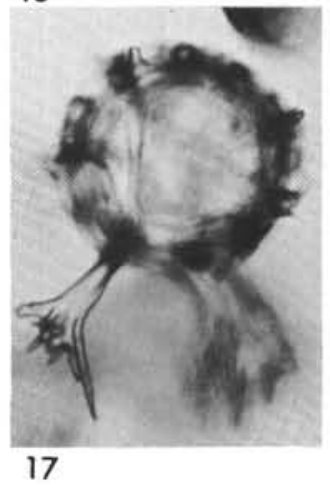




\section{PLATE 5}

\section{All specimens $\times 400$}

Figures 1-21 Corythospyris fiscella Goll n. sp.

1-4. Sample 338-10-2, 60-62 cm, atypical specimen with short lattice spines around open portions of lattice shell, front view, basal view, oblique back view, and back view, respectively.

5-7. Sample 338-13-1, 145-147 cm, front views, focused on sagittal ring and lattice shell, and back view, respectively.

8 , 10. Sample 338-13-1, 145-147 cm, oblique back views focused on upper and lower surfaces of lattice shell, respectively.

9. Sample $338-10-2,60-62 \mathrm{~cm}$, oblique back view of specimen with sternal pore.

11-13. Sample, 338-13-1, 145-147 cm, back view, right-side views focused on lattice shell and sagittal ring, respectively.

14-18. Sample 338-13-1, 145-147 cm, front view, left-side views focused on lattice shell and sagittal ring, basal view, respectively.

19. Sample 338-13-1, 145-147 cm, front view.

20-21. Sample 338-8-3, 45-47 cm, back views, focused on basal lattice spines and lattice shell, respectively.

Figures 22,23 Specimen transitional between Corythospyris jubata and Corythospyris fiscella. Sample 338-8-3, $45-47 \mathrm{~cm}$, front views focused on lattice shell and sagittal ring, respectively. 
PLATE 5

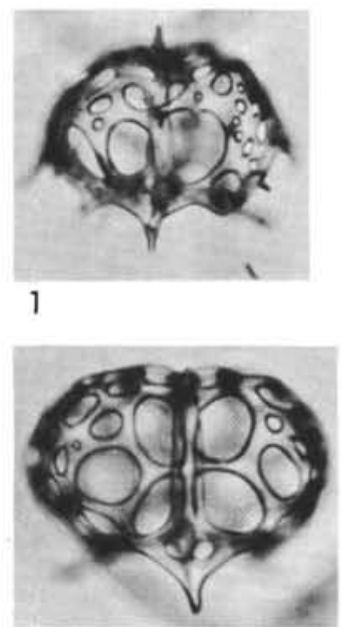

5
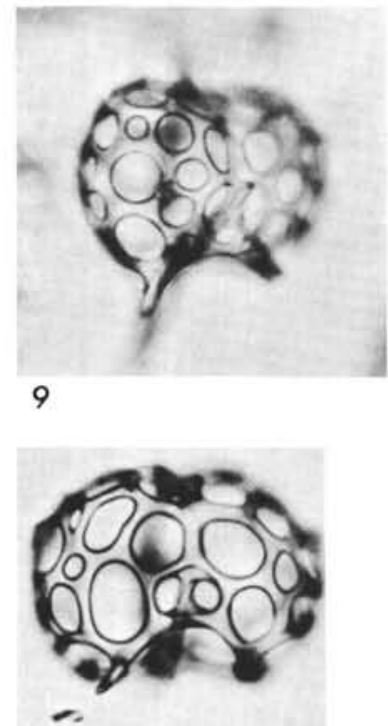

11

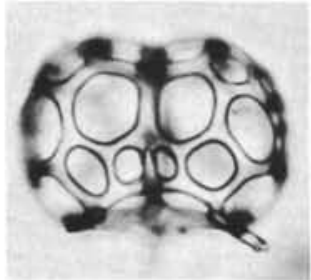

15

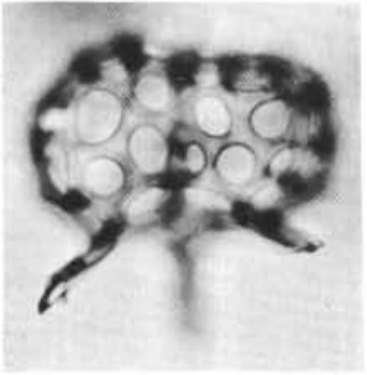

20

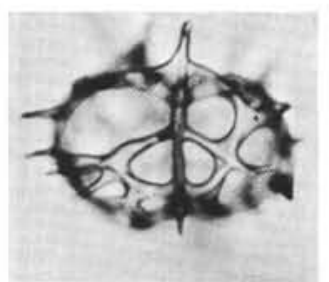

2

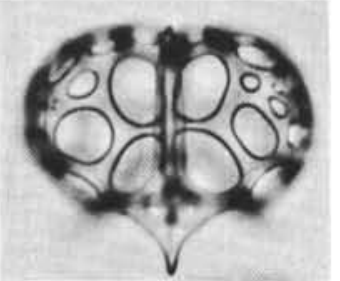

6
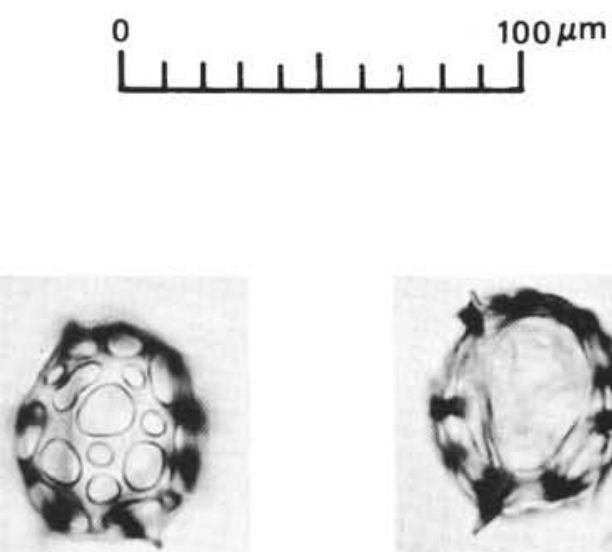

12

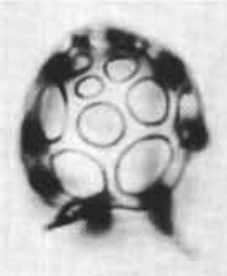

16

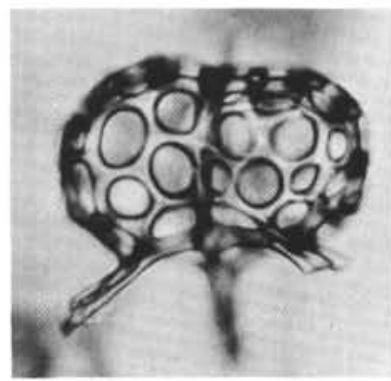

21

3

7

13

22
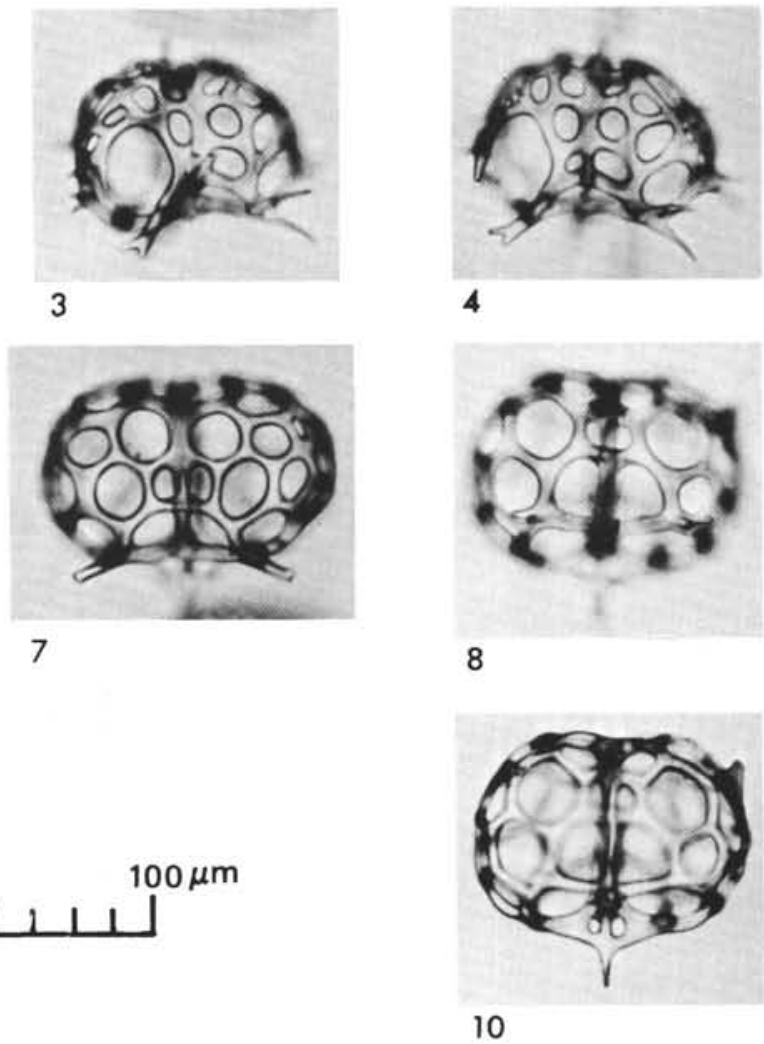

10
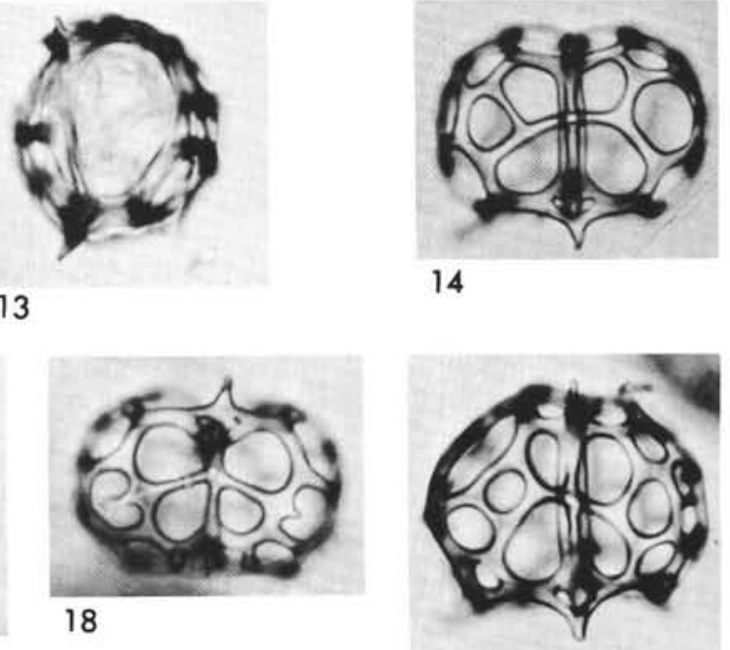

19
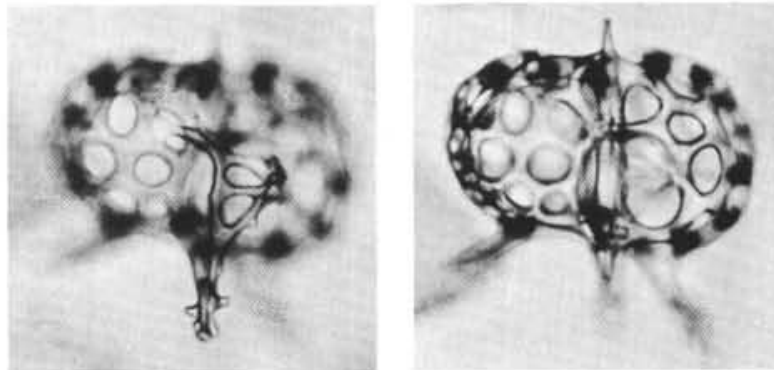

23 